\title{
A Longitudinal Analysis of Customer Satisfaction and Share of Wallet: Investigating the Moderating Effect of Customer Characteristics
}

Customer loyalty is an important strategic objective for all managers. Research has investigated the relationship between customer satisfaction and loyalty in various contexts. However, these predominantly cross-sectional studies have focused on customer retention as the primary measure of loyalty. There has been little investigation into the impact on share of wallet. Using data from the Canadian banking industry, this research aims to (1) provide the first longitudinal examination of the impact of changes in customer satisfaction on changes in share of wallet and (2) determine the moderating effects of customer age, income, education, expertise, and length of relationship. Data from 4319 households using 12,249 observations over a five-year period indicate a positive relationship between changes in satisfaction and share of wallet. In particular, the initial satisfaction level and the conditional percentile of change in satisfaction significantly correspond to changes in share of wallet. Two variables, income and length of the relationship, negatively moderate this relationship. Other demographic and situational characteristics have no impact.

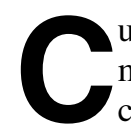
ustomer loyalty is an important strategic objective of managers around the world. A worldwide survey of chief executive officers conducted by the Conference Board (Bell 2002) found that customer loyalty and retention was the most important challenge that chief executive officers believed they faced. Despite managers' emphasis on loyalty, however, brand loyalty is widely reported to be declining (Chancy 2001). Compared with the more exclusive loyalty of the past, consumers increasingly hold polygamous loyalty to brands (Bennett and RundleThiele 2005; Rust, Lemon, and Zeithaml 2004; Uncles, Dowling, and Hammond 2003; Uncles, Ehrenberg, and Hammond 1995). As a result, customers are increasingly dividing their purchases among multiple brands in a category. For example, Kraft Foods defines a loyal customer as someone who purchases $70 \%$ or more of the same brand within a category over three years. On the basis of this benchmark, 30 years ago, $40 \%$ of Kraft's customers would

Bruce Cooil is Professor of Management, Owen Graduate School of Management, Vanderbilt University (e-mail: bruce.cooil @owen.vanderbilt. edu). Timothy L. Keiningham is Senior Vice President and Head of Consulting, Ipsos Loyalty (e-mail: tim.keiningham@ipsos-na.com). Lerzan Aksoy is Assistant Professor of Marketing, College of Administrative Sciences and Economics, Koç University (e-mail: laksoy@ ku.edu.tr). Michael Hsu is Associate Vice President, Ipsos Reid (e-mail: michael.hsu@ipsosreid.com). Bruce Cooil acknowledges support from the Dean's Fund for Faculty Research, Owen Graduate School of Management, Vanderbilt University.

To read and contribute to reader and author dialogue on JM, visit http://www.marketingpower.com/jmblog. have been classified as loyal. Today, that number is closer to 15\% (Zabin and Brebach 2004).

Jones and Sasser (1995, p. 94) assert that "the ultimate measure of loyalty ... is share of purchases in the category" (i.e., share of wallet). Although this may be an overstatement, because share of wallet is not as forward looking as other measures of loyalty (Oliver 1999), it is frequently used by researchers to operationalize loyalty behavior (e.g., Bowman, Farley, and Schmittlein 2000; Bowman and Narayandas 2004; Brody and Cunningham 1968; Cunningham 1956, 1961; Wind 1970). In an effort to increase customers' share of spending with a brand, managers have focused on improving customers' level of satisfaction. Rust (2002) explains the logic as follows: "Customer satisfaction and delight have a tremendous impact on customer retention and customer loyalty, and the result of that is that you keep customers around longer, and you also get a higher share of their wallet."

Early research supports the suggested link between satisfaction and share of wallet (Baumann, Burton, and Elliott 2005; Bowman and Narayandas 2004; Keiningham, Perkins-Munn, et al. 2005; Keiningham, Perkins-Munn, and Evans 2003; Perkins-Munn et al. 2005; Silvestro and Cross 2000). In managerial terms, the relevance of such a linkage is that changes in customers' levels of satisfaction are presumed to correspond to changes in customers' share-ofwallet allocations. Yet despite the widespread recognition that "marketers should examine changes in customer satisfaction over time" when evaluating satisfaction's impact on customer behavior (Bolton, Lemon, and Verhoef 2004, p. 277), research examining the relationship between satisfaction and share of wallet has disregarded temporal effects and has relied almost exclusively on cross-sectional (single 
point in time) data. Therefore, estimations of the impact of changes in satisfaction on share of wallet over time cannot comfortably be made, nor can inferences of causality.

In addition, research has found that the nature of the relationship between satisfaction and customer behavior (repurchase intention and retention) is moderated by the differentiating characteristics of various customer groups (e.g., age, sex, education) (Mittal and Kamakura 2001). Currently, however, no research exists that examines the effect of customer characteristics on the relationship between satisfaction and share of wallet. ${ }^{1}$

The objectives of this article are to (1) provide the first longitudinal examination of the association between customer satisfaction and customers' share of spending (share of wallet) and (2) test the moderating effect of customer characteristics on this relationship. The data used to investigate the proposed relationships consist of 4319 Canadian households whose banking relationships were tracked for a minimum of three years. Share of wallet represents the percentage of the business that households allocate to various financial institutions for different banking products/services across all financial institutions that the household uses.

\section{Theoretical Background}

\section{Customer Satisfaction and Share of Wallet}

Customer satisfaction has traditionally been regarded as a fundamental determinant of long-term consumer behavior (Oliver 1980; Yi 1990). Much of the research on customer satisfaction and customers' actual behavior has focused on the relationship between satisfaction and retention. This emphasis is largely the result of early research, which identified customer retention as a key driver of firm profitability (Reichheld 1993, 1996; Reichheld and Kenny 1991; Reichheld, Markey, and Hopton 2000; Reichheld and Sasser 1990).

Capraro, Broniarczyk, and Srivastava (2003, p. 164) observe that "today, most firm's programs to control customer defections center heavily on the management of customer satisfaction." Research appears to support this approach. Many studies have linked customer satisfaction to purchase behavior (Anderson and Sullivan 1993; Bolton 1998; Jones and Sasser 1995; LaBarbera and Mazursky 1983; Loveman 1998; Mittal and Kamakura 2001; Newman and Werbel 1973; Rust and Zahorik 1993; Sambandam and Lord 1995). Furthermore, the majority of researchers

1This study examines share of wallet rather than retention or loyalty. Indeed, there is a relationship among share of wallet, retention, and loyalty, but they are distinct constructs in the literature. Simplistically, definitions for the three can be understood as follows: Share of wallet is the percentage of money a customer allocates in a category that is assigned to a specific firm. Retention is a measure of the continuance of a relationship with a firm (i.e., it can be only 0 or 1). Loyalty is "a deeply held commitment to rebuy or re-patronize a preferred product/service in the future" (Oliver 1999, p. 34). As such, loyalty is a multidimensional construct. There is no universally accepted definition of loyalty in the literature, but it is typically believed to consist of an attitudinal and a behavioral component (Uncles, Dowling, and Hammond 2003). attempting to conceptualize and operationalize the chain of effects from satisfaction to profits have proposed models that link satisfaction to retention and retention to profits (e.g., Anderson and Mittal 2000; Heskett et al. 1994; Rust, Zahorik, and Keiningham 1995; Zeithaml, Berry, and Parasuraman 1996).

Recently, however, researchers and managers have begun to question fundamental aspects of the relationship between customer retention and firm profitability (Carroll 1991-1992; Carroll and Rose 1993; Coyles and Gokey 2002; Gupta and Lehmann 2005; Keiningham, Vavra, et al. 2005; Reinartz and Kumar 2000, 2002). One such question pertains to how loyalty is conceptualized and measured. Researchers and managers have become increasingly interested in consumers' share of spending as a behavioral measure of customer loyalty (Keiningham, Aksoy, et al. 2005; Uncles, Dowling, and Hammond 2003). For example, Zeithaml $(2000,76)$ notes a "growing popularity of the concept of 'share of wallet."' Research conducted by McKinsey \& Company also supports this change in focus from retention to share of wallet, and Coyles and Gokey (2002) find that efforts to improve customers' share of spending and customer retention can add as much as ten times greater value to a company than focusing on retention alone.

Marketing theory and empirical research lend credibility to this shift in focus. Zeithaml (2000) proposes a model in which customer retention leads to firm profits in one of four ways: (1) lowering costs to service customers, (2) the ability to charge premium prices, (3) word of mouth, and (4) increased volume of purchase (i.e., increased share of wallet). However, Reinartz and Kumar (2000, 2002) find that customer retention does not result in loyal customers costing less to serve, paying higher prices for the same bundle of services, or marketing the company through word of mouth. Therefore, this implies that the primary path from retention to firm profitability in Zeithaml's (2000) proposed model is through increased share of wallet.

Rust, Lemon, and Zeithaml (2004) also note that the way researchers have treated customer retention does not accurately portray customers' actual behavior patterns, observing that researchers frequently treat customers who defect as "lost for good." They argue that a "more realistic scenario" is that customers may leave and return and be either serially monogamous or polygamous in terms of the number of firms with which they conduct business in the category. This treatment of retention closely mirrors the concept of share of wallet. The observation that consumers continuously leave and return to a product, service, or institution over a period of time is consistent with commonly used measures of share of category spending (Stern and Hammond 2004). Typically, consumers' share of spending across a broad range of business sectors is measured as the share of purchases customers provide to a particular brand in the category over a fixed period (Cunningham 1956; Jones and Sasser 1995; Zabin and Brebach 2004).

Retention and share of wallet, though not identical, are closely related. The finding that consumers engage in serially monogamous or polygamous relationships with companies unequivocally implies a close link between retention/ repurchase and share of category spending (share of wallet). 
Therefore, it is reasonable to expect that satisfaction and share of wallet are positively associated. This is supported by current marketing theory. In their model of customer asset management of services, Bolton, Lemon, and Verhoef (2004) propose that customer satisfaction has a positive influence on cross-buying, a proposition supported by several researchers (Anderson and Sullivan 1993; Cronin and Taylor 1992; Parasuraman, Zeithaml, and Berry 1988; Verhoef, Franses, and Hoekstra 2001; Zeithaml, Berry, and Parasuraman 1996); in other words, customer satisfaction is related to customers' allocation of a greater share of their spending to the firm.

In addition, Bowman and Narayandas (2004) and Keiningham, Aksoy, and colleagues (2005) conceptualize and operationalize the satisfaction-profit chain that Anderson and Mittal (2000) propose, which links satisfaction to retention as (1) satisfaction to (2) share of wallet to (3) revenue to (4) profit. The substitution of share of wallet for retention in the satisfaction-profit chain is further supported by Perkins-Munn and colleagues' (2005) research, which shows that the two constructs are highly correlated and that the relationship between attribute satisfaction and retention is similar to the relationship between attribute satisfaction and share of wallet.

Empirical research appears to confirm the link between satisfaction and share of wallet across various industries. Researchers have found a positive relationship between satisfaction and share of wallet for the fleet trucking (PerkinsMunn et al. 2005), pharmaceutical (Perkins-Munn et al. 2005), institutional securities (Keiningham, Perkins-Munn, et al. 2005), retail banking (Baumann, Burton, and Elliott 2005), processed metals (Bowman and Narayandas 2004), and grocery retailing (Mägi 2003; Silvestro and Cross 2000) industries. To date, however, research into the relationship between satisfaction and share of wallet has relied exclusively on cross-sectional data. Bernhardt, Donthu, and Kennett (2000, p. 164) also assert that "the true impact of satisfaction on performance measures is not apparent when taking a cross-sectional approach. A longitudinal view seems to be necessary."

Although longitudinal examinations of the effect of customer satisfaction on other performance measures have found a positive relationship to customer retention (Bolton 1998), firm revenues (Bernhardt, Donthu, and Kennett 2000; Gruca and Rego 2005; Ittner and Larcker 1998), and shareholder value (Anderson, Fornell, and Mazvancheryl 2004; Fornell 2003; Fornell et al. 2006; Gruca and Rego 2005), the impact on share of wallet currently remains elusive.

Given the findings of cross-sectional studies regarding satisfaction and share of wallet and the findings of longitudinal studies regarding the relationship between satisfaction and other performance variables, we hypothesize the following (see Figure 1):

$\mathrm{H}_{1}$ : The relationship between a change in customer satisfaction and a contemporaneous change in current share of wallet is positive.

The effects of customer satisfaction on customer behavior and business results are widely believed to be nonlinear and asymmetric (Anderson and Mittal 2000; Coyne 1989; Jones and Sasser 1995; Keiningham and Vavra 2001; Oliva, Oliver, and MacMillan 1992). The nonlinearity and asymmetry of the relationship between customer satisfaction and repurchase intentions has been confirmed in several studies (Bloemer, Kasper, and Lemmink 1990; DeSarbo et al. 1994; Mittal and Baldasare 1996; Mittal et al. 1998; Oliver, Rust, and Varki 1997). Mittal and Kamakura (2001) find that this nonlinear and asymmetric relationship also holds true for repurchase. Likewise, Anderson (1998) finds that

FIGURE 1

The Model and Hypotheses

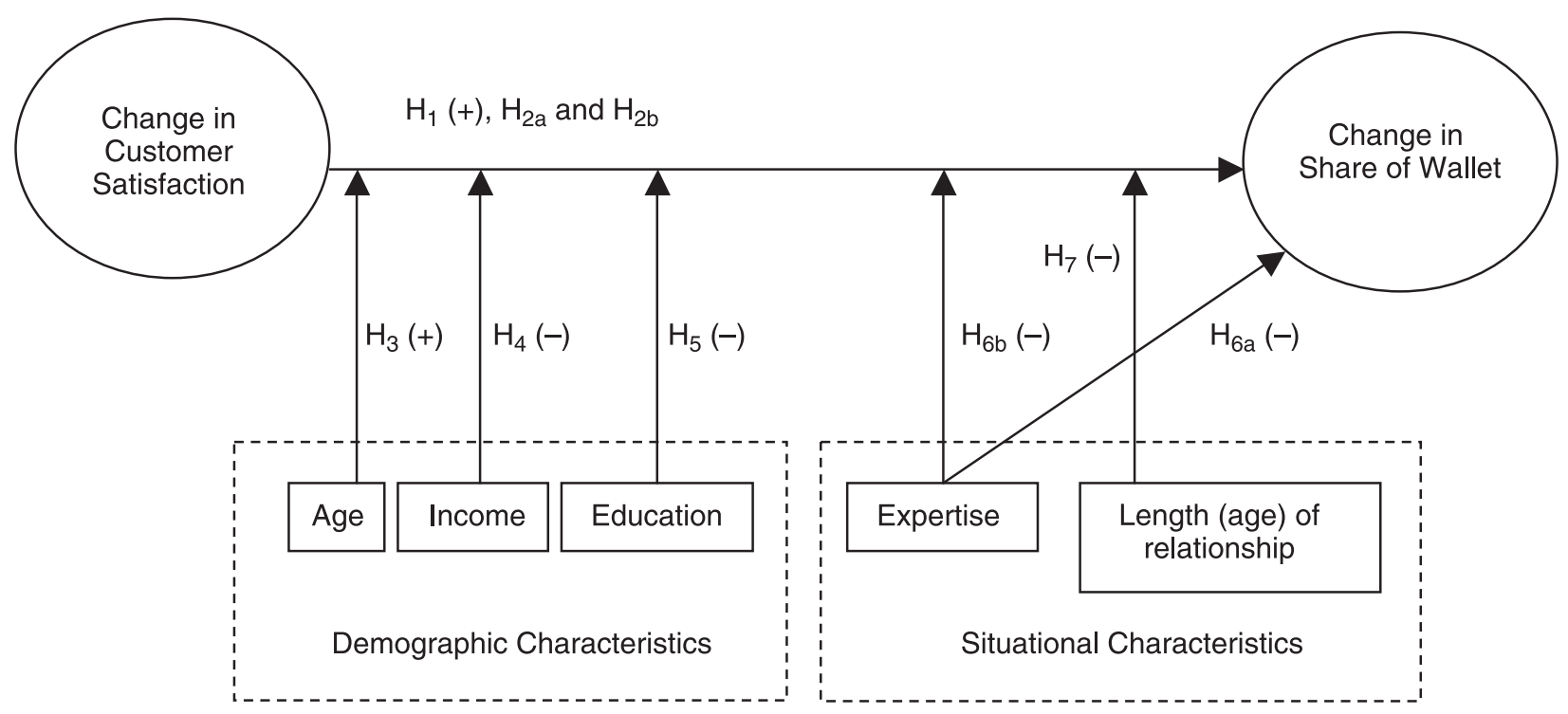


the relationship between customer satisfaction and word of mouth is asymmetric and nonlinear.

Similarly, recent research on customer loyalty and share of wallet has uncovered nonlinear relationships. Austin and Singh (2005) report curvilinear effects of the determinants of loyalty intentions. Keiningham, Perkins-Munn, and Evans (2003) and Bowman and Narayandas (2004) find a positive, nonlinear relationship between satisfaction and share of wallet.

These findings can be explained, in part, through research on expectations. Satisfaction is "strongly influenced by customer expectations" (Rust, Zahorik, and Keiningham 1994, p. 42). Researchers have found multiple expectation thresholds. As expectations converge with respect to what is expected to happen, what should happen, and what would happen in the "ideal" situation, firms achieve greater competitive positioning (Boulding et al. 1993; Miller 1977; Swan and Combs 1976). This implies that there are expectation thresholds based on the consistency of delivery that must be met for customers to consider a firm.

The research on expectations interlocks well with the research of Kano (1997), Oliver (1997), and Anderson and Mittal (2000) regarding satisfaction. In particular, these researchers propose that there are thresholds with regard to performance of a particular attribute on customer satisfaction. Furthermore, Anderson and Mittal (2000) and Keiningham and Vavra (2001) propose that similar thresholds exist with regard to changes in customer satisfaction and changes in customer behavior (i.e., unless satisfaction levels reach a certain threshold, changes in satisfaction will have little impact on customer behavior). Early findings support such a relationship. In a longitudinal examination of customer satisfaction and sales performance for two retailers, Keiningham and colleagues (2006) find that the relationship between changes in satisfaction and changes in sales is determined, in part, by customers' baseline levels of satisfaction.

As a result, we do not expect that changes in share of wallet are linearly related to changes in satisfaction (as measured directly on a Likert scale). In particular, we expect that the baseline level of satisfaction affects the relationship between changes in satisfaction and changes in share of wallet.

Furthermore, the effect of satisfaction on share of wallet has been shown to differ by customer type (segment). Keiningham, Perkins-Munn, and Evans (2003) study the relationship between satisfaction and share of wallet, examining the impact of different organizational buyer groups. Their findings show that the relationship between satisfaction and share of wallet varies considerably by buyer group and that the relationship is nonlinear. Similarly, Baumann, Burton, and Elliott (2005) find that customer characteristics affect share-of-wallet allocations in retail banking; in particular, they find that age is positively associated with share of wallet. Thus:

$\mathrm{H}_{2}$ : The positive relationship between changes in share of wallet and changes in satisfaction (a) depends on the baseline satisfaction level and (b) differs by customer segment.

\section{Moderators in the Satisfaction-Share-of-Wallet Relationship}

There is a stream of research that consistently finds variations in satisfaction ratings based on numerous customer characteristics (e.g., Bryant and Cha 1996; Mittal and Kamakura 2001; Peterson and Wilson 1992; Ross et al. 1999; Varki and Rust 1997; Venn and Fone 2005). Recently, it has been found that customer characteristics moderate the relationship between satisfaction and behavioral outcomes (Baumann, Burton, and Elliott 2005; Mägi 2003; Mittal and Kamakura 2001; Homburg and Giering 2001; Homburg, Giering, and Menon 2003; Keiningham, Perkins-Munn, and Evans 2003).

However, such analyses should not be limited solely to traditional demographic variables (e.g., age, education, income). Situational characteristics, such as price orientation (Kim, Srinivasan, and Wilcox 1999; Mägi 2003), tenure of relationship (Homburg, Giering, and Menon 2003), expertise (Andreassen and Lindestad 1998; Chiou, Droge, and Hanvanich 2002), involvement (Bloemer and Kasper 1995; Bloemer and Odekerken-Schröder 2002; Homburg and Giering 2001), and purchase volume (Mägi 2003), have all been found to influence the relationship between satisfaction and customer behavior. In this study, we investigate three demographic (age, income, and education) and two situational (expertise and tenure) variables. We specifically selected these variables because a stream of prior research has shown each to affect customer loyalty. A brief discussion of each of these potential moderators and their corresponding effects follows.

Age. Age moderates the relationship between satisfaction and loyalty (Baumann, Burton, and Elliott 2005; Homburg and Giering 2001). In particular, older consumers are more loyal to a particular brand than younger consumers in the automotive (Homburg and Giering 2001; LambertPandraud, Laurent, and Lapersonne 2005) and banking (Baumann, Burton, and Elliott 2005) industries.

However, the expected relationship between age and loyalty has not been universal. A large-scale study by American Association of Retired Persons finds that older consumers are just as likely to switch brands or experiment with alternative brands as are younger consumers (Moos 2004). Mittal and Kamakura (2001) find that the relationship between satisfaction scores and repurchase behavior for cars is stronger for younger than for older consumers. Age has also been negatively linked to customer share (East et al. 1995; East et al. 2000). East and colleagues (2000) propose that older consumers have more free time, are able to spend more time shopping, and thus are able to shop at multiple stores. Some studies have found that the middleage segment is the most loyal. Wright and Sparks (1999) find high loyalty in the 35-44 age group, and McGoldrick and Andre (1997) state that loyal shoppers are more likely to be the middle-age group. Conversely, Mägi (2003) finds that age does not moderate the relationship between satisfaction and loyalty for grocery consumers.

Despite contradictory findings regarding the impact of age, studies in the industry under examination, banking (see 
Baumann, Burton, and Elliott 2005), suggest a positive impact. In addition, Lambert-Pandraud, Laurent, and Lapersonne (2005) apply four age-related theoretical perspectives to explain why age and loyalty should be positively associated: biological aging, cognitive decline, socioemotional selectivity, and change aversion. Applying this to the banking industry context, (1) biological aging suggests that increasing physical impairment associated with age reduces the number of banks customers use; (2) cognitive decline suggests that because of the reduced ability to evaluate complex options, older customers reduce their consideration set (i.e., number of banking relationships); (3) socioemotional selectivity suggests that older customers place a greater emphasis on feelings and emotions, and therefore, in the case of retail banking, older customers should be more interested in the relationship experience; and (4) change aversion is expected to increase with age, and therefore, in the context of banking, the risk older customers associate with switching banks is likely to be considered greater than it is for younger customers. Thus:

$\mathrm{H}_{3}$ : The impact of a change in customer satisfaction on change in share of wallet increases with the consumer's age.

Income. A large body of research suggests that income is negatively linked to customer loyalty (Crask and Reynolds 1978; Korgaonkar, Lund, and Price 1985; Zeithaml 1985). Because higher-income consumers have fewer shopping restrictions, they are believed to exhibit less loyalty than low-income consumers (Sharir 1974; Zeithaml 1985). In addition, Homburg and Giering (2001) find that income is an important, negative moderator of the satisfaction-loyalty relationship.

However, findings regarding the relationship between income and customer behavior are not unanimous. In a study of online services, Keaveney and Parthasarathy (2001) find that online service "continuers" have higher average income levels than switchers. In the case of automobiles, Evans (1962) finds that fewer dealers are visited as incomes rise.

The discrepancy may be explained, in part, by customers' perceptions of the cost of time (Farley 1964a). A high-income consumer is believed to hold a higher valuation of time (Frank, Green, and Sieber 1967; Goldman and Johansson 1978; Marmorstein, Grewal, and Fishe 1992; Murthi and Srinivasan 1999). Therefore, a higher-income consumer may be more willing to trade off time in favor of a choice on the basis of limited evaluation, meaning that a consumer with a higher income may be less likely to evaluate in certain product categories. Indeed, there is empirical evidence that shows that income is negatively related to external search (Beatty and Smith 1987; Udell 1966).

Sharir (1974) argues that as households' cost of time increases, it affects customers' behavior in one of two ways: (1) Customers reduce their time spent buying goods (e.g., in search, deliberation, decision making), thus reducing consideration set size and increasing brand loyalty, or (2) customers avoid searching for information and deliberating on the brands to be bought, their sequence, and their shares and may buy at random (as with impulse buying), thus decreas- ing brand loyalty. Sharir argues that both patterns are likely to be relevant, but it is impossible to know a priori.

However, by its very nature, increased wealth provides greater opportunities to obtain a greater variety of financial products. Economic barriers affect the ability of lowerincome and moderate-income households to hold various financial products (Barr 2004). In addition, customers' financial needs change as affluence increases (Asher 2001). Furthermore, several banking institutions compete primarily for high-income customers (Bielski 2004), whereas retail banking services are designed to have appeal across income levels.

Therefore, given that higher-income people have greater opportunities for more diverse financial products, that there is greater competition for their business, and that selection of financial products has a direct income-relevant component that may offset time costs, we hypothesize the following:

\section{$\mathrm{H}_{4}$ : The impact of a change in customer satisfaction on change in share of wallet decreases with the consumer's income level.}

Education. Prior research tends to show that higher levels of education are associated with lower levels of customer loyalty (Chance and French 1972; Mittal and Kamakura 2001; Murphy 1978). People with higher education levels are believed to engage in greater information gathering and usage before decision making (Capon and Burke 1980). As a result, more highly educated consumers have greater awareness of alternatives. Furthermore, people with higher levels of education tend to be associated with higher income levels (Farley1964b), and as we noted previously, higher income can be associated with lower levels of loyalty. A notable exception has been found with regard to online services. As with the relationship between income and loyalty, however, Keaveney and Parthasarathy (2001) find that online service continuers have higher average education levels than switchers. Given that most previous studies have shown that higher levels of education are associated with lower levels of loyalty, we hypothesize the following:

$\mathrm{H}_{5}$ : The impact of a change in customer satisfaction on change in share of wallet decreases as the consumer becomes more educated.

Expertise. Previous research shows that consumer expertise can influence customer loyalty (Bell, Auh, and Smalley 2005; Maheswaran 1994; Mitchell and Dacin 1996). East (1992) argues that higher levels of knowledge lead to lower levels of customer loyalty because knowledge provides customers with information about competing alternatives. Moorthy, Ratchford, and Talukdar (1997) argue that as customers gain experience, they use more attributes and more attribute levels to differentiate among offerings. This is likely due to the difference between novices' and experts' associative knowledge networks. Experts have more developed and complex cognitive structures than novices (Alba and Hutchinson 1987). As a result, experts may be more likely to be receptive to competitive offerings. Because 
novices find it more difficult to make comparisons, they perceive greater risk in decision making (Heilman, Bowman, and Wright 2000) and thus prefer to stay more loyal.

Capraro, Broniarczyk, and Srivastava (2003) conducted tests to determine whether knowledge mediates or moderates the satisfaction-customer retention linkage. However, their research supports neither mediation nor moderation, instead concluding that both knowledge and satisfaction independently influence customer defections. Given the preceding controversy, we propose the following alternate hypotheses:

$\mathrm{H}_{6 \mathrm{a}}$ : Higher levels of expertise are negatively associated with a change in share of wallet, after the effects of other moderators are adjusted for.

$\mathrm{H}_{6 \mathrm{~b}}$ : The impact of a change in customer satisfaction on change in share of wallet decreases with higher levels of consumer expertise.

Length of relationship. Firm-customer relationships are evolutionary, time-adjusted associations. With repeated interactions, firms and customers develop bonds, and the reinforcements from satisfactory interactions help build customer loyalty (Anderson and Sullivan 1993; Anderson and Weitz 1989).

Customers with positive experiences over time are less likely to defect and are more forgiving (Anderson and Sullivan 1993). As a result, customers' judgments of recent exchange outcomes are influenced by the cumulative effect of long-term experiences with the product, service, or institution (Kalwani and Narayandas 1995). Thus, in the case of relationships that have aged, shifts in satisfaction have a weaker impact on loyalty. In addition, with time and effort investments, switching costs tend to increase, making it more difficult to switch.

Prior research tends to support this finding. Homburg, Giering, and Menon (2003) find that the longer the relationship between the buyer and the seller, the weaker the relationship is between customer satisfaction and customer loyalty. Thus:

$\mathrm{H}_{7}$ : The impact of a change in customer satisfaction on change in share of wallet decreases with an increase in the length of relationship between the consumer and the company.

\section{Methodology}

\section{Data Collection and Measurement}

The data we used in this study were collected as part of an ongoing national panel study of Canadian bank customers for the years 2000-2004. More than 10,000 Canadian households are surveyed annually; information is gathered on all financial products (deposit, loan, and investment) and all financial institutions that each household used. Respondents are selected from across Canada, with representative sampling designed to mirror the geodemographic profile of Canadian households. When possible, respondents are tracked for multiple years. For the purpose of this investigation, we used only households that responded in two or more consecutive years.

This study provides sufficient information on 4319 households to test the seven hypotheses (16\% for two years,
$40 \%$ for three years, $23 \%$ for four years, and $21 \%$ for five years). For these households, there are 12,249 observations. Among the observed changes in share of wallet at each institution, 34\% involve only "money-in" transactions (e.g., checking accounts, savings, investments), $1 \%$ involve only "money-out" transactions (e.g., loans, lines of credit, credit cards), and $65 \%$ involve both types of business (see Table 1). Share of wallet represents the percentage of total business, in dollars, conducted with the financial institution (e.g., total dollars with the institution divided by total dollars across all financial institutions; i.e., customers' relationships with all bank entities are recorded).

We measured overall satisfaction for the institution or institutions (up to three) that the respondent believed to be primary. We measured satisfaction on a four-point semantic scale (4 = "extremely satisfied," 3 = "somewhat satisfied," 2 = "somewhat dissatisfied," 1 = "extremely dissatisfied"). In addition, we included several customer characteristics in the study: age, income, education, length of relationship, and expertise. We did not measure expertise directly. Instead, we asked respondents if they used various professional financial advisory services. The use of such professional advisors could logically indicate (1) a degree of sophistication on the part of the customer and (2) direct access to subject-matter experts. It is reasonable to presume that use of financial advisors indicates a customer's desire to better manage his or her financial assets.

We recognize that a counterargument can be made about the use of a financial advisor. It might simply be a proxy for the respondent's lack of expertise. Although we believe that the former explanation is more probable than the latter, under either scenario, the use of a financial advisor would be construed as a proxy for expertise, the former being a positive association and the latter being a negative one. However, the variable we use here indicates only whether a customer used advisory services and provides

\section{TABLE 1 \\ Broad Breakdown of Types of Money-In and Money-Out Products Under Analysis}

\author{
Money-In Products \\ - Checking and savings accounts \\ - Guaranteed investment certificatesa \\ -Bondsb \\ -Stocksb \\ -Mutual fundsb \\ $\bullet$ (Pensions are excluded)

\section{Money-Out Products \\ -Credit cards \\ -Mortgages \\ -Personal loans \\ -Lines of credit (secured, unsecured)}

aThese are deposit investment securities sold by Canadian banks and trust companies. They are often bought for retirement plans because they provide a low-risk fixed rate of return. The principal is at risk only if the bank defaults.

bThere is no Glass-Stegall equivalent in Canada to separate commercial banking from investment banking/securities brokerage. 
TABLE 2

Descriptive Statistics for 4319 Households and First Follow-Up

\begin{tabular}{|c|c|c|c|c|c|c|}
\hline Variable Type & Variable & M & SD & First Quartile & Mdn & Third Quartile \\
\hline \multicolumn{7}{|l|}{ Dependent } \\
\hline & TB_SOW change (\%) & 0 & 28 & -8 & 0 & 7 \\
\hline Salisiaction & Initial (category) & - & - & Satisfied & Extremely satisfied & Extremely satisfied \\
\hline & $\begin{array}{c}\text { Age (years) } \\
\text { Income }(\$ 1,000 \text { category) } \\
\text { Education (category) } \\
\text { Tenure (years) }\end{array}$ & $\begin{array}{c}53 \\
- \\
- \\
5.8\end{array}$ & $\begin{array}{l}15 \\
- \\
- \\
1.6\end{array}$ & $\begin{array}{c}42 \\
25-30 \\
9-13 \text { years } \\
5.0\end{array}$ & $\begin{array}{c}53 \\
45-55 \\
\text { Some college } \\
7.0\end{array}$ & $\begin{array}{c}65 \\
70-100 \\
\text { Certificate/diploma } \\
7.0\end{array}$ \\
\hline Business Activity & $\begin{array}{l}\text { TB_soW }(\%) \\
\text { Money-in }(\$ 1,000) \\
\text { Money-out }(\$ 1,000) \\
\text { Money-out/TB }(\%)\end{array}$ & $\begin{array}{c}50 \\
139.1 \\
36.8 \\
32\end{array}$ & $\begin{array}{c}37 \\
247.2 \\
55.1 \\
47\end{array}$ & $\begin{array}{c}11 \\
8.3 \\
.00 \\
0\end{array}$ & $\begin{array}{l}48 \\
46.9 \\
9.6 \\
0\end{array}$ & $\begin{array}{l}90 \\
156.5 \\
62.5 \\
100\end{array}$ \\
\hline
\end{tabular}

Notes: Satisfaction decreased for $15 \%$ of first follow-ups (14\% of all follow-ups); initial satisfaction was at either "satisfied" or "extremely satisfied" and did not move out of this range for $67 \%$ of first follow-ups $(69 \%$ of all follow-ups). Additional information on other household characteristics at baseline: $78 \%$ sought professional advice, and $32 \%$ had only money-in accounts. TB_SOW = total business share of wallet.

only limited information about customer expertise. Table 2 provides descriptive statistics on the 4319 households used in this study.

\section{Model Development}

We used a two-level latent class regression model to predict annual changes in the share of wallet per household with each financial institution. This model allows for household random effects, so that even though the data across households are assumed to be independent, the observations per household are independent only after conditioning on this random effect. This is a natural extension of the conventional approach, in that the probability of belonging to a given latent class is still a logistic function of covariates, but these covariates now include the household random effect (Vermunt 2003). This random effect has a mean of zero and a variance that is specific to the latent class. We estimated parameters with maximum likelihood estimation. The mathematical details appear in the Appendix. Lenk and DeSarbo (2000) also use random effects in a latent class framework, though their approach is mathematically and conceptually different.

To represent the change in satisfaction, we tested several candidate predictors, including the conditional percentile of change given the initial satisfaction level, the ordinal change in Likert scale units, indicators for any increase and any decrease, and indicators for whether a customer moved from a satisfied (Levels 3 or 4) to a dissatisfied (Levels 1 or 2) state and for any change in the other direction. Exploratory best-subsets analyses and preliminary restricted latent class model analysis indicated that the conditional percentile of change in satisfaction was the most important predictor and that other measures of change in satisfaction did not provide significant incremental value. The conditional percentile of change in satisfaction is the change in household satisfaction (from the original Likert scale) expressed as a conditional percentile relative to all other households that started at the same level of satisfaction.

\section{Covariates for Latent Class}

Preliminary latent class analyses showed that covariates representing the type and dollar level of household transactions from the last period were more important than household demographics for predicting total business share of wallet. Thus, we used the following covariates: the last period's values of (1) total business share of wallet (TB_SOW $\left.\mathrm{t}_{-1}\right)$, (2) total dollar amount of money-in accounts $\left(\mathrm{MI}_{\mathrm{t}-1}\right)$, (3) total dollar amount for money-out transactions (see Table 1) (money-out: $\mathrm{MO}_{\mathrm{t}-1}$ ), and (4) the proportion of total business in money-out transactions $\left([\mathrm{MO} / \mathrm{TB}]_{\mathrm{t}-1}\right)$.

\section{Predictors for Change in Total Business Share of Wallet}

We used these same four variables as candidate predictors for total business share of wallet in the regression equations, along with an indicator for whether all business was in money-in transactions. Other candidate predictors included all the information about the moderating variables we proposed in $\mathrm{H}_{3}-\mathrm{H}_{7}$ : household income, the length of time households used the services of the institution (tenure), whether they used financial advisory services (advisory), and the age and education of the head of the household who was taking the survey. We expressed household income and all education variables as percentiles relative to the sample. We measured brand effects by including indicators for the financial institution.

\section{Model Selection}

Initially, we included all information about transactions and household characteristics as predictors, along with the indicators for financial institution. We found the optimal number of latent classes by minimizing the Bayesian informa- 
tion criterion (BIC; Schwarz 1978; see also Bozdogan 1987). We chose BIC because it is a consistent criterion under general conditions (Rao and Wu 1989; Woodroofe 1982), and there is substantial theoretical and empirical work that suggests that it is effective in finding a good scientific model in many settings (Rust et al. 1995; Steyerberg et al. 2001), including latent class analyses (Biernacki and Govaert 1999; Dias 2004). We then modified the model by backward stepwise elimination of predictors and simplification across latent classes, in which the least significant predictors were removed (or refit with class independent coefficients when the difference in coefficient estimates across latent classes did not approach significance). At each step, we redetermined the corresponding optimal number of latent classes until there was no improvement in BIC (for additional details, see the Appendix). The final model also minimized the consistent Akaike information criterion (AIC) (Bozdogan 1987), but the analysis indicated that minimization of AIC (Akaike 1974) and AIC3 (Bozdogan 1994) would require much more complicated models (at least 17 latent classes).

\section{Model Fit}

Inferences made from linear latent class models are asymptotically valid under relatively general conditions and allow for considerable departures from normality (Satorra 2002). However, we also checked the validity of the model in several ways. Overall, the residual analyses and other model diagnostics indicate that there are no serious problems with model fit.

Residual diagnostics. In the final model, there is no significant serial correlation in the household residuals at Lag 1 and Lag 2 (in each case, $p>.3$ ). The nominal serial correlations indicate that less than one-tenth of $1 \%$ of the variance in residuals can be related to autocorrelation. This could be due to several factors, including the broad selection of candidate predictors, the differenced form of the dependent variable, and the model's facility (through segmentation and random effects) to accommodate longitudinal and cross-sectional heterogeneity effectively. We also tested stationarity over time by performing a one-way analysis of variance of residuals by year. The results indicate that there are no significant differences in average residual by year $(p=.63)$, and this is true even when the analysis is restricted to residuals from annual changes in share of wallet that are two or more years from the household's baseline $(p=.71)$. These analyses also support homoskedasticity of residuals across years. Finally, the plot of residuals versus predicted values does not suggest that there are any problems with the assumption that errors have a constant mean of zero across prediction levels.

Multicollinearity. For the coefficients that are related to $\mathrm{H}_{1}-\mathrm{H}_{7}$, the estimated variance inflation factors (VIFs) were always less than 2 across segments. The estimated VIFs for the structural coefficients of variables that describe account activity $\left(\mathrm{TB}_{-} \mathrm{SOW}_{\mathrm{t}-1}, \mathrm{MI}_{\mathrm{t}-1}\right.$, and $\left.\mathrm{MO}_{\mathrm{t}-1}\right)$ are larger, presumably because these variables are also used as covariates for latent class membership. Even in this latter case, esti- mated VIFs do not exceed 3.5 (still substantially below the benchmark of 5 , which is an indication of high multicollinearity).

Effect of extremes. We also calculated the Cook distance that corresponded to each residual. The distribution of these influence values is not significantly correlated with the size of the dependent variable (rank correlation $=-.005, p=$ .557 ; raw correlation $=-.001, p=.882$ ), and the occurrence of a Cook distance $>.5$ (which happens only $2 \%$ of the time, less than expected in the classical case) is only marginally correlated with the absolute size of the dependent variable (rank correlation $=.015, p=.104)$.

\section{The Best Scientific Model}

The model that minimized BIC is the 14-class model that Table 3 summarizes. Overall, it accounts for $95 \%$ of the change in total business share of wallet, but within the largest latent class (50\% of households), the R-square is only $63 \%$, the third lowest among all latent classes.

It is difficult to classify each case accurately into the appropriate latent class. A case represents an observed change in a household's total business share of wallet (along with the concomitant covariates and predictors for that household). The model makes classification errors with an estimated probability of $29.7 \%$, and the proportional reduction in the entropy of classification is $70.2 \%$ when the model's posterior probabilities are used rather than the marginal probabilities of each latent class (Kamakura and Wedel 1995). For Class 1, the coefficient of the randomerror effect (which has a mean of zero) is much larger than any of the other covariate effects, so the estimate that $50 \%$ of cases (and $50 \%$ of households) belong to this class is based primarily on the large estimated variance of the random effect.

These results indicate that, in many cases, it may be difficult to identify the most appropriate segment for an individual household. This is to be expected for a random effects model, and this uncertainty is a function of the natural heterogeneity among households. Reducing the number of segments can also improve these classification statistics, but such a reduction should be done only after fitting the best scientific model for segmentation, which typically includes segments that may be difficult to recognize. A manager should focus on the larger, more identifiable segments. Nevertheless, it is the more complex model, which may include managerially irrelevant segments, that provides the most accurate way of identifying segments for which targeted corporate efforts would be most profitable and the best framework for a rigorous examination of the hypotheses under study.

\section{Profiles of the Primary Latent Classes}

Table 3 describes the profiles in terms of the dependent variable, change in TB_SOW (change between times $t$ and $\mathrm{t}-1$ ), the contemporaneous change in satisfaction, and other variables measured in initial period $(\mathrm{t}-1)$. As Table 3 shows, the first two latent classes are similar to each other and unique among the 14 customer segments in several ways: 


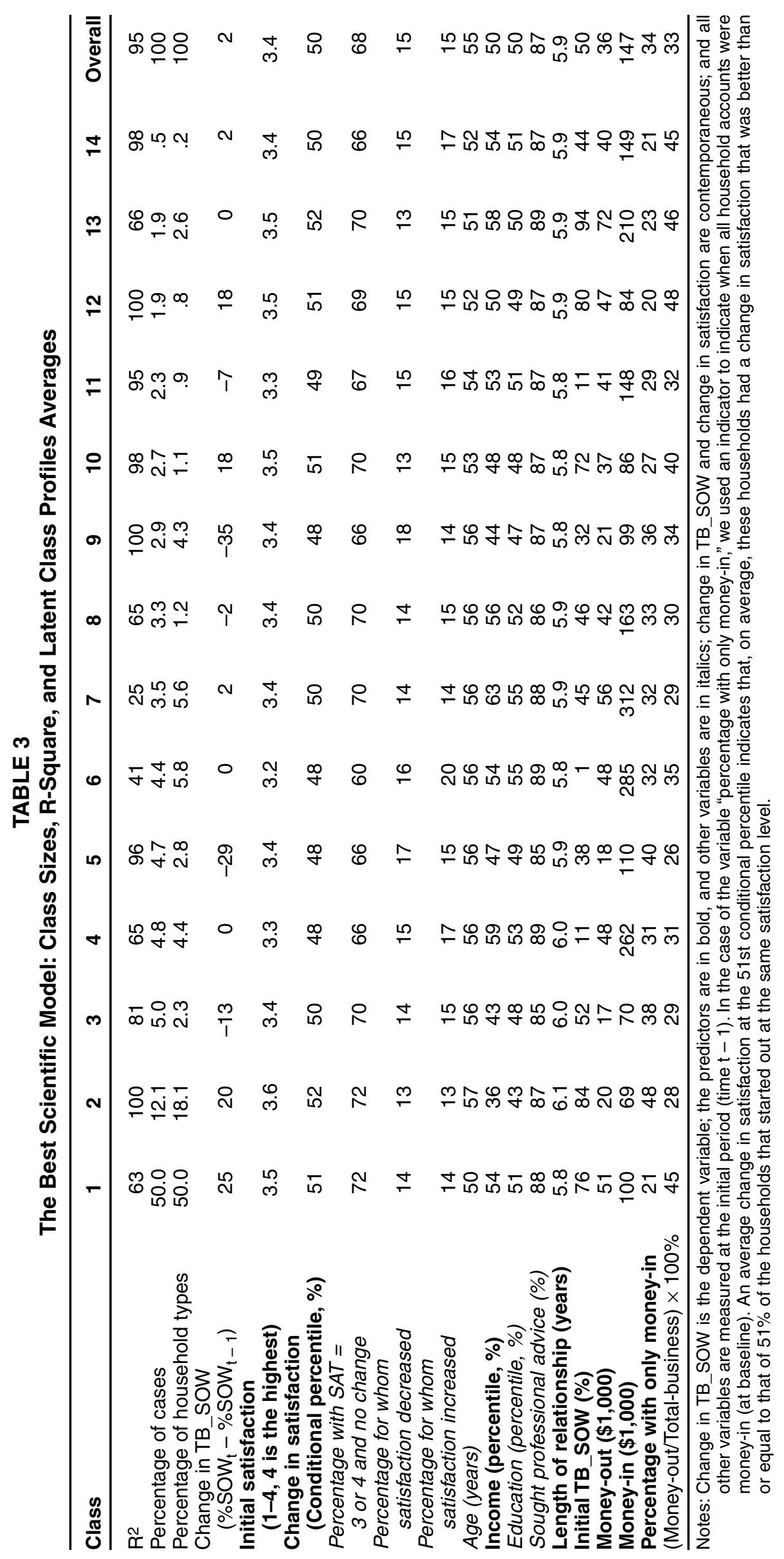


-They are the largest segments (Class 1: $50 \%$ of cases and households; Class 2: $12 \%$ of observations and 18\% of households);

-They have high initial satisfaction (Class 1 is the third highest, and Class 2 is the highest): extremely satisfied $=56 \%$ and $60 \%$ for Classes 1 and 2, respectively, and somewhat satisfied $=39 \%$ and $31 \%$, respectively;

-They remain at high levels of satisfaction: In each class, $72 \%$ of households were initially at one of the two highest levels of satisfaction and remained at precisely the same level during the next period (this is the highest level of high unchanged satisfaction among all classes); and

-They have large average values of total business share of wallet with a primary institution: $76 \%$ and $84 \%$ for Classes 1 and 2 , respectively.

However, the two largest classes also differ dramatically in terms of demographic characteristics and the type of business they conduct with their primary institutions:

-Class 1 has the lowest average age (50), and Class 2 has the highest average age (57);

-In Class 1 , education is slightly above average (64\% with some college), and Class 2 has the lowest average education (51\% with some college);

-In Class 1 , the average income is slightly above the median (54th percentile), and Class 2 has the lowest average among all classes (36th percentile);

-In Class 1 , the tenure of the relationship with the primary institution is just below the average among all classes (5.8 years), and Class 2 has the longest average tenure among classes (6.1 years); and

- Class 1 has the largest percentage of total business in the money-out category among classes, representing more than $1 \%$ of households ( $45 \%$ money-out), and Class 2 has the second-lowest percentage of money-out business among all classes $(28 \%)$.

\section{Predictor Significance in the Latent Class Regressions}

Three covariates used to determine the latent class were also of preeminent importance as predictors $\left(\mathrm{TB}_{-} \mathrm{SOW}_{\mathrm{t}-1}\right.$, $\mathrm{MI}_{\mathrm{t}-1}$, and $\left.\mathrm{MO}_{\mathrm{t}-1}\right)$, along with the indicator for whether all household transactions (of the last period) were moneyin. As Table 4 shows, the other important predictors were income, tenure, the conditional percentile of change in satisfaction, and the initial satisfaction level. Tested across all classes, all predictors have significantly nonzero coefficients $(p<.0001)$ that are also significantly different across classes $(p<.0001)$. Brand (the actual financial institution) did not have any significant incremental value for predicting the change in total business share of wallet, and therefore we did not include it in these models. In this discussion of predictor effects, we refer to the actual average change in total business share of wallet $\left(\mathrm{TB}_{-} \mathrm{SOW}_{\mathrm{t}}-\mathrm{TB}_{-} \mathrm{SOW}_{\mathrm{t}-1}\right)$ in which each term is expressed as a percentage. This is the difference between successive values of share of wallet, so even though it is also expressed in units of percent, it does not actually represent the percentage change in share of wallet relative to the actual baseline level of share of wallet.

\section{Effects of Last Period's Business Type and Dollar Amount}

The last period's total business share of wallet $\left(\right.$ TB_SOW $_{\mathrm{t}-1}$ ) has a negative coefficient in every class, indicating that, on average, customers tend to make smaller positive or even negative adjustments to TB_SOW when it is already at higher levels, all else being equal. In contrast, the dollar level for money-in and money-out can have either a positive or a negative impact, depending on the latent class, but it always has an impact of less than $.1 \%$ on total business share of wallet per thousand dollar increase in level. Similarly, the coefficient of the indicator for whether all business consists of money-in transactions can also be negative or positive. The largest coefficient estimate is in the largest latent class (Class 1), but even here, the effect is an average reduction of only $2 \%$ in the in total business share of wallet for households in which all transactions are money-in relative to households in which there is also money-out business. Nevertheless, the coefficients of these predictors (and the others we discuss subsequently) are highly significant and significantly different across classes (for both tests on each predictor, $p<.0001$ ).

TABLE 4

\section{Latent Class Regression Coefficients for Predictors Representing Satisfaction and Satisfaction} Moderators in Classes That Represent at Least $4 \%$ of Either Cases or Household Types

\begin{tabular}{|c|c|c|c|c|c|c|c|c|}
\hline & 1 & 2 & 3 & 4 & 5 & 6 & 7 & 9 \\
\hline \multicolumn{9}{|l|}{ Class } \\
\hline$R^{2}$ & 63 & 100 & 81 & 65 & 96 & 41 & 25 & 100 \\
\hline Percentage of cases & 50 & 12 & 5 & 5 & 5 & 4 & 4 & 3 \\
\hline Percentage of household types & 50 & 18 & 2 & 4 & 3 & 6 & 6 & 4 \\
\hline \multicolumn{9}{|l|}{ Predictor Coefficients } \\
\hline Initial satisfaction (1-4, 4 is the highest) & 2.0 & .0 & .9 & 1.0 & .9 & .1 & -.1 & .0 \\
\hline Change in satisfaction ( $50 \%$ change in conditional percentile) & 2.7 & .0 & 5.1 & 6 & 2.1 & .1 & .8 & .0 \\
\hline Income (percentile, \%) & -2.9 & -.0 & -10.1 & -1.0 & .5 & .1 & -2.0 & .4 \\
\hline Length of relationship (years) & -.2 & .0 & .6 & -.3 & .6 & .0 & .5 & -.0 \\
\hline
\end{tabular}

Notes: Each coefficient represents change in TB_SOW $\left(\% \mathrm{SOW}_{t}-\% \mathrm{SOW}_{\mathrm{t}-1}\right)$ per unit change in predictor, all else being equal. For change in conditional percentile of satisfaction, one unit change in this predictor represents a comparison between the third and the first quartiles of the distribution of annual changes in satisfaction among households that started at the same satisfaction level. All coefficients are significantly nonzero and significantly different across classes (for each test, $p<.0001$ ). 


\section{Results}

\section{The Effect of Change in Satisfaction $\left(\mathrm{H}_{1}\right.$ and $\left.\mathrm{H}_{2}\right)$}

Remarkably, among all the predictors, only the conditional percentile of change in satisfaction has a nearly consistent positive coefficient in each regression (Table 4), in support of $\mathrm{H}_{1}$. The only exception is Class 11 (not shown in Table 4 ), which represents approximately $2 \%$ of the observed changes in profiles and represents less than $1 \%$ of all households; yet even in this case, it is not significantly negative (the one-sided $p$ value is .45 ), representing less than onetenth of $1 \%$ average change in total business share of wallet, even for households that undergo the highest possible percentile of change in satisfaction. In the largest latent class (50\% of observations and households), total business share of wallet increases by an average of $2.7 \%$ per 50 -percentile increase in satisfaction (relative to customers who started at the same satisfaction level). Nevertheless, as Table 4 shows, among the other latent classes that each represent at least $4 \%$ of households (Classes 2, 4, 6, and 7), the increases in total business share of wallet are less than $1 \%$ per 50 percentile increase in satisfaction, and with the exception of Class 1 , the average increase per household is only .3\% per 50 -percentile increase in satisfaction. These changes assume that adjustments for other household characteristics (e.g., type and level of business, tenure, income, and initial satisfaction level) have been made.

These results confirm a significant and positive, though somewhat modest, relationship between change in satisfaction and the concomitant change in total business share of wallet. This relationship differs by latent class and baseline satisfaction level, but it is strongest in the largest class $(50 \%$ of households). Among the four classes that represent at least $4 \%$ of households, the largest class is characterized by the second-largest average volume of money-out business $(\$ 51,000)$ and the largest proportion $(45 \%)$ of money-out dollars as a proportion of total business; thus, these are the types of customers who generate a large share of a financial institution's profits.

After correcting for other variables in the model, including the initial satisfaction level, the best model posits a linear relationship per unit change in conditional percentile within latent class. However, this is not a linear relationship relative to the Likert scale, and it is not a constant linear relationship in percentile units across latent classes $(p<$ .0001). Furthermore, this within-class relationship requires an adjustment for initial satisfaction level. Because satisfaction is not measured on a ratio scale, its coefficient is interpreted as the parameter needed to calculate a new intercept on the basis of initial satisfaction ([original segment intercept + segment coefficient] $\times$ [baseline satisfaction on the Likert scale]), which changes by segment. In this way, it represents a segment-specific coefficient that provides a new anchor point for how share of wallet changes with each baseline satisfaction level, and this adjustment changes in an approximately linear way relative to the Likert scale (after we correct for change in satisfaction on a conditional percentile scale and for other moderating and structural variables).
In the largest latent class and in all other classes except three (of which only Class 7 is large enough to be in Table 4), total business share of wallet also increases per increased level of initial satisfaction. These adjustments are modest (always less than $4 \%$ per Likert point). In the largest latent class, the coefficient represents an average increase of $2 \%$ per Likert point. In summary, the results are consistent with $\mathrm{H}_{2}$; we find a positive relationship between changes in share of wallet and changes in satisfaction that differs by customer segment and also depends on the baseline satisfaction level.

\section{Moderators for the Effects of Change in Satisfaction $\left(\mathrm{H}_{3}-\mathrm{H}_{7}\right)$}

We tested the variables referred to in the seven hypotheses for incremental value in the model. Initially, we considered all these variables candidates, and we eliminated each in turn only if a better scientific model (lower BIC) could be obtained by doing so. In each case, we tested the effects of each variable after correcting for the effects of the other variables that are in the final (best scientific) model.

$\mathrm{H}_{3}$. Overall, there is no evidence that age is a positive moderator. The age of the head of the household does not seem to have any significant incremental value $(p=.18)$. Among the four largest latent classes (Classes 1, 2, 6, and 7, representing $50 \%, 18 \%, 6 \%$, and $6 \%$ of households, respectively), change in satisfaction has the strongest effect in Class 1, in which the head of the household tends to be an average of at least five years younger. Thus, $\mathrm{H}_{3}$ is not supported.

$H_{4}$. Income is an important predictor in the final model and thus is significant and significantly different across classes (in both cases, $p<.0001$ ). It has a negative coefficient in 9 of the 14 latent classes, and these 9 classes represent $86 \%$ of all households. Its effects, however, are modest. Its largest negative impact is in Class 1 , in which there is a $1.7 \%$ average decrease in total business share of wallet per 50-percentile increase in income, conditional on fixed levels of change in satisfaction and other household characteristics. These results support $\mathrm{H}_{4}$, that income tends to moderate the relationship between changes in satisfaction and changes in total business share of wallet negatively.

$H_{5}$. Education is not a predictor in the best model and does not have significant incremental value in this model $(p=.74)$. There is a high correlation between income and education $(\mathrm{r}=.987, p<.0001$, in which both variables are measured in terms of percentiles), so it can be used as a proxy for income; as such, it would be a negative moderator (as $\mathrm{H}_{5}$ posited), but income seems to be more directly related to changes in total business share of wallet.

$H_{6}$. The indicator for whether financial advisory services were used was not in the final model and did not have any incremental value when we added it $(p=.29)$. Therefore, there is no support for $\mathrm{H}_{6}$ regarding the effects of expertise. However, the variable we used here indicates only whether a customer used advisory services and provides only limited and hypothetical information about the actual moderating effects of customer expertise. 
$H_{7}$. Length of relationship (tenure) with the financial institution was a significant predictor in the final model and had significantly different effects across classes (in both tests, $p<.0001)$. Its coefficient is negative in Class 1 , in which there is an average decrease of .2\% in total business share of wallet per year of tenure. It is never greater than its value in Class 3, which represents $2 \%$ of households and in which there is an average increase of .6\% in total business share of wallet per year. Thus, its overall effect is modest; the average effect per household is $-.08 \%$ per year. The coefficient is negative in only 4 of the 14 latent classes, but these 4 classes represent $60 \%$ of households. Thus, there is strong empirical support for the significance of this variable, and though its effects are modest, it tends to be a negative moderator (as hypothesized).

\section{General Discussion and Conclusions}

Our analysis advances the empirical research on the intuitive relationship between customer satisfaction and business outcomes in two key ways. First, our findings indicate that changes in satisfaction are positively and nonlinearly related to the share of wallet a customer allocates to a particular service provider over time; specifically, the initial satisfaction level and the conditional percentile of change in satisfaction significantly correspond to changes in share of wallet.

Second, the findings suggest that the relationship between satisfaction and share of wallet is moderated by both demographic and situational customer characteristics. In particular, income and length of relationship are significant predictors in the model. Both income and length of relationship negatively moderated the relationship between changes in satisfaction and share of wallet. This corresponds to similar findings regarding the relationships between satisfaction and repurchase intention and between satisfaction and retention (Mittal and Kamakura 2001).

The key implication is that managers should not simply strive to improve reported satisfaction levels without an understanding of the relationship to customers' share-ofwallet allocations. Given that both the initial satisfaction level and the conditional percentile of change in satisfaction are significantly associated with changes in share of wallet, it is critical that managers design their efforts to improve satisfaction so that customers reach the satisfaction levels that correspond to higher share-of-wallet levels. This may require a reevaluation of the means with which managers currently measure the potential return on investment from improvement efforts aimed at changing customer behavior through improved customer satisfaction, particularly if cross-sectional analyses are currently used. Cross-sectional (as opposed to longitudinal) examinations of the relationship between customer satisfaction and customer behavior may be unable to identify adequately the roles of both baseline satisfaction levels and change in satisfaction on customers' share-of-wallet allocations.

Furthermore, simply treating all customers as homogeneous has the potential to misrepresent the relationship between satisfaction and share of wallet. Therefore, it is important that the level of influence of various customer segments on share of wallet be uncovered so that resources can be appropriately allocated to those areas, thus providing the greatest impact. For example, in this study, there is an interesting contrast between the households in the two largest classes; households in Class 1 tend to be clients with more income and a larger volume of money-out business than clients in Class 2, and they are also more responsive to both higher baseline satisfaction levels and positive changes in satisfaction.

The influence of satisfaction on customers' share-ofwallet allocations to a bank has strategic implications for managers. As opposed to retention (i.e., the business relationship is on/off), the ability to manipulate share of wallet demonstrates that many, if not most, customers have relationships with multiple financial institutions rather than an exclusive/monogamous relationship with an individual institution. Therefore, customers are more likely to be aware of competitors' offerings and to have some level of interaction with competing institutions. Knowledge and experience lower customers' perceived risk (Rust, Zahorik, and Keiningham 1994). Consequently, changes in service levels that affect the level of customer satisfaction can more easily result in the inflow or outflow of money to the firm. Given the increasingly polygamous loyalty that consumers hold toward firms/brands (Bennett and Rundle-Thiele 2005; Rust, Lemon, and Zeithaml 2004; Uncles, Dowling, and Hammond 2003; Uncles, Ehrenberg, and Hammond 1995), this issue is likely to transcend the banking industry.

\section{Limitations and Further Research}

This study used data from a business-to-consumer relationship within a single industry. As such, the results cannot be immediately applied to different industries or to businessto-business relationships. Similarly, this study focuses exclusively on the relationship between overall satisfaction levels and share of wallet. More comprehensive models that account for the relationship between attribute-level satisfaction and share of wallet could provide managers with important insights into more tactical measures that firms could take to improve the percentage of business their customers give to them versus to their competition.

In addition, this article investigated the moderating influence of three demographic (age, income, and education) and two situational (expertise and tenure) customer characteristics variables. However, firms use a host of customer characteristics to segment their customer bases. In many cases, our findings differed from those previously hypothesized in or logically inferred from prior research. Finally, our analysis identified the presence of a statistically significant relationship only between changes in share of wallet and concomitant changes in satisfaction, along with the statistically significant and insignificant effects of moderating variables. We did not prove causation. Therefore, to examine the robustness of these findings, additional research should be conducted regarding both the longitudinal relationship between satisfaction and share of wallet and the moderating influence across several customer characteristics in various industries and countries. 


\section{Appendix}

We modeled the change in total business share of wallet with a two-level latent class regression across $\mathbf{J}$ groups $(\mathrm{J}=$ 4319 households) and $\mathrm{K}$ latent classes. Here, $\mathrm{y}_{\mathrm{ij}}$ represents the ith observed change in total business share of wallet at household $\mathrm{j}\left(\mathrm{i}=1, \ldots, \mathrm{n}_{\mathrm{j}}\right)$. The log-likelihood is

$$
\begin{gathered}
\log \mathrm{L}=\sum_{\mathrm{j}=1}^{\mathrm{J}} \log \\
\int_{\xi_{\mathrm{i}}}\left[\prod_{\mathrm{i}=1}^{\mathrm{n}_{\mathrm{j}}} \mathrm{f}\left(\mathrm{y}_{\mathrm{ij}} \mid \mathrm{Z}_{\mathrm{ij}}^{\text {cov }}, \mathrm{Z}_{\mathrm{ij}}^{\text {pred }}, \xi_{\mathrm{j}}, \boldsymbol{\Theta}\right)\right] \mathrm{f}\left(\xi_{\mathrm{j}}\right) \mathrm{d}\left(\xi_{\mathrm{j}}\right),
\end{gathered}
$$

where the parameters, $\boldsymbol{\Theta}$, include the covariate parameters, $\Gamma$, used in the logistic model for the latent classes and regression coefficients $\mathbf{B}=\left(\beta^{(1)}, \ldots, \beta^{(\mathrm{K})}\right)$, where $\beta^{(\mathrm{k})}$ is the vector of coefficients used in the regression model for $y_{i j}$ within latent class $\mathrm{k}, \mathrm{k}=1, \ldots, \mathrm{K}$. In Equation A1, the integration is with respect to the vector of random effects $\xi=$ $\left(\xi_{1}, \ldots, \xi_{\mathrm{J}}\right)$, which, as we show subsequently, accommodates differences among the $\mathrm{J}$ households. Let $\mathrm{X}_{\mathrm{ij}}$ represent the latent class variable so that $\mathrm{P}\left(\mathrm{X}_{\mathrm{ij}}=\mathrm{k}\right)$ is the probability that observation $\mathrm{i}$ from household $\mathrm{j}$ belongs to latent class $\mathrm{k}$. Then, the $\mathrm{K}$ latent class density for $\mathrm{y}_{\mathrm{ij}}$, which is referred to in Equation A1, is

$$
\begin{gathered}
\mathrm{f}\left(\mathrm{y}_{\mathrm{ij}} \mid \mathrm{Z}_{\mathrm{ij}}^{\mathrm{cov}}, \mathrm{Z}_{\mathrm{ij}}^{\mathrm{pred}}, \xi_{\mathrm{j}}, \boldsymbol{\Theta}\right) \\
=\sum_{\mathrm{k}=1}^{\mathrm{K}} \mathrm{P}\left(\mathrm{X}_{\mathrm{ij}}=\mathrm{k} \mid \mathrm{Z}_{\mathrm{ij}}^{\mathrm{cov}}, \xi_{\mathrm{j}}, \Gamma\right) \mathrm{f}_{\mathrm{k}}\left(\mathrm{y}_{\mathrm{ij}} \mid \mathrm{Z}_{\mathrm{ij}}^{(\mathrm{pred}, \mathrm{k})}, \beta^{(\mathrm{k})}, \sigma_{\mathrm{k}}\right),
\end{gathered}
$$

where, for latent class $\mathrm{k}$, (1) the density, $\mathrm{f}_{\mathrm{k}}$, of $\mathrm{y}_{\mathrm{ij}}$ is a normal distribution with variance $\sigma_{\mathrm{k}}^{2}$ and a mean $\mu_{\mathrm{k}}$ that is a linear

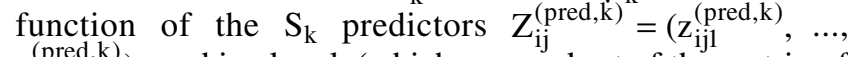
$\mathrm{z}_{\mathrm{ij}}^{(\text {pred,k) }} \mathrm{k}_{\mathrm{k}}$ ) used in class $\mathrm{k}$ (which are a subset of the matrix of all predictors, $\mathrm{Z}_{\mathrm{ij}}^{\text {pred }}$, used in the model), with coefficients $\beta^{(\mathrm{k})}=\left(\beta_{0}^{(\mathrm{k})}, \beta_{1}^{(\mathrm{k})}, \ldots, \beta_{\mathrm{S}_{\mathrm{k}}}^{(\mathrm{k})}\right)$,

$$
\mu_{\mathrm{k}}=\beta_{0}^{(\mathrm{k})}+\sum_{\mathrm{r}=1}^{\mathrm{S}_{\mathrm{k}}} \beta_{\mathrm{r}}^{(\mathrm{k})} \mathrm{z}_{\mathrm{ijr}}^{(\text {pred, } \mathrm{k})}
$$

and (2) $\mathrm{P}\left(\mathrm{X}_{\mathrm{ij}}=\mathrm{k} \mid \mathrm{Z}_{\mathrm{ij}}^{\mathrm{cov}}, \xi_{\mathrm{j}}, \Gamma\right)$ is the logistic probability that observation $\mathrm{i}$ from household $\mathrm{j}$ is in latent class $\mathrm{k}$,

$$
\mathrm{P}\left(\mathrm{X}_{\mathrm{ij}}=\mathrm{k} \mid \mathrm{Z}_{\mathrm{ij}}^{\mathrm{cov}}, \xi_{\mathrm{j}}, \Gamma\right)=\frac{\exp \left[\eta\left(\mathrm{k} \mid \mathrm{Z}_{\mathrm{ij}}^{\mathrm{cov}}, \xi_{\mathrm{j}}\right)\right]}{\sum_{\ell=1}^{\mathrm{K}} \exp \left[\left(\eta\left(\ell \mid \mathrm{Z}_{\mathrm{ij}}^{\mathrm{cov}}, \xi_{\mathrm{j}}\right)\right]\right.},
$$

where

$$
\eta\left(\ell \mid \mathrm{Z}_{\mathrm{ij}}^{\text {cov }}, \xi_{\mathrm{j}}\right)=\gamma_{\ell 0}+\sum_{\mathrm{r}=1}^{\mathrm{R}} \gamma_{\ell \mathrm{r}} \mathrm{z}_{\mathrm{ijr}}^{\mathrm{cov}}+\gamma_{\ell 00} \xi_{\mathrm{j}}
$$

for $\ell=1, \ldots, \mathrm{K}$. In Equations A4 and A5, the $\xi_{\mathrm{j}}, \mathrm{j}=1, \ldots, \mathrm{J}$, are assumed to be independent standard normal random effects, which is not restrictive given the flexibility that is provided in Equation A5 by the random effect coefficients, $\gamma_{\ell 00}$, which correspond to each latent class $\ell, \ell=1, \ldots, \mathrm{K}$, and are subject to the identifiability constraint $\Sigma_{\ell=1}^{\mathrm{K}} \gamma_{\ell 00}=$ 0 .

\section{Departures from Normality}

Statistical inferences based on normality have been shown to remain valid and even asymptotically efficient under general conditions that permit substantial departures from normality, even in the case of latent class models (Satorra 2002). In this case, the validity of inferences under nonnormality is even less of an issue because of the bounded nature of the dependent variable (because Huber's condition on the projection matrices is satisfied; see Arnold 1981, Chap. 4; Huber 1980, pp. 155-60). Inferences are subject to the correct specification of the linear model and require random error, which is also homoskedastic within each class, but the diagnostics we discussed previously (see the "Model Fit" subsection) provide substantial empirical evidence that these assumptions are met.

\section{Model Selection Procedure}

Preliminary latent class analyses indicated that four variables (the last period's values of TB_SOW $\mathrm{TH}_{-1}, \mathrm{MI}_{\mathrm{t}-1}$, $\mathrm{MO}_{\mathrm{t}-1}$, and $[\mathrm{MO} / \mathrm{TB}]_{\mathrm{t}-1}$ ), all of which describe the account activity at baseline, were important and natural covariates for determining the latent class. These covariates were highly significant in all multiple latent class models. In addition, we included all information on transactions and household characteristics, along with the indicators for financial institution, as predictors (for the dependent variable, change in TB_SOW) in the initial model. Given this selection of covariates and the preliminary selection of all candidate predictors, we found the optimal number of latent classes by minimizing the BIC (Schwarz 1978; see also Bozdogan 1987). We then modified the model with a backward stepwise procedure in which, at each step, we experimented with (1) the elimination of the predictor that was least significantly nonzero (according to a joint Wald test for whether it was significantly nonzero in any class) and (2) the simplification of predictors by fitting them with class-independent coefficients (when the coefficient estimate were not significantly different across classes). When we eliminated predictors, it was necessary to redetermine the optimal number of classes, but ultimately we made these modifications only if BIC improved. In a final stage of the analysis, we retried a forward step with each predictor that had been eliminated to determine whether a better model was possible. In the final model, all predictors have coefficients that differ by latent class.

Stepwise procedures do not always lead to global optima. The optimal subset of covariates and predictors typically depend on the number of latent classes modeled. It might be considered ideal to perform a best-subsets analysis for each plausible selection of the number of classes and then choose the best model from among those solutions. Nevertheless, our own search indicates that the optimal number of classes changes only slightly, if at all, as the set of covariates and predictors change. 


\section{REFERENCES}

Akaike, Hirotugu (1974), "A New Look at the Statistical Model Identification," IEEE Transactions on Automatic Control, 19 (6), 716-23.

Alba, Joseph and Wesley Hutchinson (1987), "Dimensions of Consumer Expertise," Journal of Consumer Research, 13 (4), 411-55.

Anderson, Erin and Barton Weitz (1989), "Determinants of Continuity in Conventional Industrial Channel Dyads," Marketing Science, 8 (4), 310-23.

Anderson, Eugene W. (1998), "Customer Satisfaction and Wordof-Mouth," Journal of Service Research, 1 (August), 1-14.

—, Claes Fornell, and Sanal K. Mazvancheryl (2004), "Customer Satisfaction and Shareholder Value," Journal of Marketing, 68 (October), 172-85.

_ and Vikas Mittal (2000), "Strengthening the SatisfactionProfit Chain," Journal of Service Research, 3 (2), 107-120.

- and Mary W. Sullivan (1993), "The Antecedents and Consequences of Customer Satisfaction for Firms," Marketing Science, 12 (Spring), 125-43.

Andreassen, Tor Wallin and Bodil Lindestad (1998), "Customer Loyalty and Complex Services: The Impact of Corporate Image on Quality, Customer Satisfaction and Loyalty for Customers with Varying Degrees of Service Expertise," International Journal of Service Industry Management, 9 (1), 7-23.

Arnold, Steven F. (1981), The Theory of Linear Models and Multivariate Analysis. New York: John Wiley \& Sons.

Asher, Joseph (2001), “'Wealth Management' Moves Center Stage," ABA Banking Journal, 93 (April), 41-46.

Austin, Clara and Jagdip Singh (2005), "Curvilinear Effects of Consumer Loyalty Determinants in Relational Exchanges," Journal of Marketing Research, 42 (February), 96-108.

Barr, Michael S. (2004), "Banking the Poor," Yale Journal on Regulation, 21 (Winter), 121-237.

Baumann, Chris, Suzan Burton, and Greg Elliott (2005), "Determinants of Customer Loyalty and Share of Wallet in Retail Banking," Journal of Financial Services Marketing, 9 (3), 231-48.

Beatty, Sharon E. and Scott M. Smith (1987), "External Search Effort: An Investigation Across Several Product Categories," Journal of Consumer Research, 14 (June), 83-95.

Bell, David (2002), "The CEO Challenge: Top Marketplace and Management Issues-2002," Research Report No. R-1322-02RR, The Conference Board, New York (October).

Bell, Simon J., Seigyoung Auh, and Karen Smalley (2005), "Customer Relationship Dynamics: Service Quality and Customer Loyalty in the Context of Varying Levels of Customer Expertise and Switching Costs," Journal of the Academy of Marketing Science, 33 (2), 169-83.

Bennett, Rebekah and Sharyn Rundle-Thiele (2005), "The Brand Loyalty Life Cycle: Implications for Marketers," Journal of Brand Management, 12 (4), 250-63.

Bernhardt, Kenneth L., Naveen Donthu, and Pamela A. Kennett (2000), "A Longitudinal Analysis of Satisfaction and Profitability," Journal of Business Research, 47 (February), 161-71.

Bielski, Lauren (2004), "Slow Buildup for 'Mass Affluent' Success," ABA Banking Journal, 96 (July), 61.

Biernacki, C. and G. Govaert (1999), "Choosing Models in Model-Based Clustering and Discriminant Analysis," Journal of Statistical Computation and Simulation, 64 (1), 49-71.

Bloemer, Josée M. and Hans D. Kasper (1995), "The Complex Relationship Between Consumer Satisfaction and Brand Loyalty," Journal of Economic Psychology, 16 (2), 311-29.

_ _ and Jos Lemmink (1990), "The Relationship Between Overall Dealer Satisfaction, Satisfaction with the Attributes of Dealer Service, Intended Dealer Loyalty and
Intended Brand Loyalty: A Dutch Automobile Case," Journal of Satisfaction, Dissatisfaction and Complaining Behavior, 3, $42-47$.

- and Gaby Odekerken-Schröder (2002), "Store Satisfaction and Store Loyalty Explained by Customer- and Store-Related Factors," Journal of Consumer Satisfaction, Dissatisfaction and Complaining Behavior, 15, 68-80.

Bolton, Ruth N. and James H. Drew (1991), "A Longitudinal Analysis of the Impact of Service Changes on Customer Attitudes," Journal of Marketing, 55 (January), 1-10.

- Katherine N. Lemon, and Peter C. Verhoef (2004), “The Theoretical Underpinnings of Customer Asset Management: A Framework and Propositions for Future Research," Academy of Marketing Science, 32 (3), 271-92.

Boulding, William, Ajay Kalra, Richard Staelin, and Valarie A. Zeithaml (1993), "A Dynamic Process Model of Service Quality," Journal of Marketing Research, 30 (February), 7-27.

Bowman, Douglas, John U. Farley, and David C. Schmittlein (2000), "Cross-National Empirical Generalization in Business Services Buying Behavior," Journal of International Business Studies, 31 (4), 667-86.

- and Das Narayandas (2004), "Linking Customer Management Effort to Customer Profitability in Business Markets," Journal of Marketing Research, 41 (November), 433-47.

Bozdogan, H. (1987), "Model Selection and Akaike's Information Criterion (AIC): The General Theory and Its Analytical Extensions," Psychometrika, 52 (3), 345-70.

Brody, Robert P. and Scott M. Cunningham (1968), "Personality Variables and the Consumer Decision Process," Journal of Marketing Research, 10 (February), 50-57.

Bryant, Everitt Barbara and Jaesung Cha (1996), "Crossing the Threshold," Marketing Research, 8 (4), 20-28.

Capon, Noel and Marian Burke (1980), "Individual, Product Class, and Task-Related Factors in Consumer Information Processing," Journal of Consumer Research, 7 (December), 314-26.

Capraro, Anthony J., Susan Broniarczyk, and Rajendra K. Srivastava (2003), "Factors Influencing the Likelihood of Customer Defection: The Role of Consumer Knowledge," Journal of the Academy of Marketing Science, 31 (2), 164-75.

Carroll, Peter (1991-1992), "The Fallacy of Customer Retention," Journal of Retail Banking, 13 (Winter), 15-20.

— and Sanford Rose (1993), "Revisiting Customer Retention," Journal of Retail Banking, 15 (Spring), 5-13.

Chance, William A. and Norman D. French (1972), "An Exploratory Investigation of Brand Switching," Journal of Marketing Research, 9 (May), 226-29.

Chiou, Jyh-Shen, Cornelia Droge, and Sangphet Hanvanich (2002), "Does Customer Knowledge Affect How Loyalty Is Formed?" Journal of Service Research, 5 (2), 113-24.

Chancy, Kevin J. (2001), "Save America's Dying Brands," Marketing Management, 10 (September-October), 36-44.

Coyles, Stephanie and Timothy C. Gokey (2002), "Customer Retention Is Not Enough," The McKinsey Quarterly, 2 (2), 81-89.

Coyne, Kevin (1989), "Beyond Service Fads: Meaningful Strategies for the Real World," Sloan Management Review, 30 (Summer), 69-76.

Crask, Melvin and Fred Reynolds (1978), "An In-Depth Profile of the Department Store Shopper," Journal of Retailing, 54 (2), 23-32.

Cronin, J. Joseph, Jr., and Steven A. Taylor (1992), "Measuring Service Quality: A Reexamination and Extension," Journal of Marketing, 56 (July), 55-68. 
Cunningham, R.M. (1956), "Brand Loyalty: What, Where, How Much?" Harvard Business Review, 34 (January-February), 116-28.

- (1961), "Customer Loyalty to Store and Brand," Harvard Business Review, 39 (November-December), 127-39.

DeSarbo, Wayne S., Lenard Huff, Marcelo M. Rolandelli, and Jungwhan Choi (1994), "On the Measurement of Perceived Service Quality: A Conjoint Analysis Approach," in Service Quality: New Directions in Theory and Practice, Roland T. Rust and Richard L. Oliver, eds. Thousand Oaks, CA: Sage Publications, 199-220.

Dias, Jose (2004), "Finite Mixture Models: Review, Applications and Computer Intensive Methods," doctoral dissertation, SOM Research School, University of Groningen, Netherlands.

East, Robert (1992), "The Effect of Experience on the Decision Making of Expert and Novice Buyers," Journal of Marketing Management, 8 (2), 167-70.

- Kathy Hammond, Patricia Harris, and Wendy Lomax (2000), "First-Store Loyalty and Retention," Journal of Marketing Management, 16 (4), 307-325.

_, Patricia Harris, Gill Willson, and Wendy Lomax (1995), "Loyalty to Supermarkets," The International Review of Retail, Distribution and Consumer Research, 5 (1), 99-109.

Evans, Franklin B. (1962), "Correlates of Automobile Shopping Behavior," Journal of Marketing, 26 (October), 74-77.

Farley, John U. (1964a), "'Brand Loyalty' and the Economics of Information," Journal of Business, 37 (October), 370-81.

_ (1964b), "Why Does 'Brand Loyalty' Vary Over Products?" Journal of Marketing Research, 1 (November), 9-14.

Fornell, Claes (2003), "Boost Stock Performance, Nation's Economy," Quality Progress, 36 (February), 25-31.

, Sunil Mithas, Forest V. Morgenson III, and M.S. Krishan (2006), "Customer Satisfaction and Stock Prices: High Returns, Low Risk," Journal of Marketing, 70 (January), 1-14.

Frank, Ronald E., Paul E. Green, and Harry F. Sieber Jr. (1967), "Household Correlates of Purchase Price for Grocery Products," Journal of Marketing Research, 4 (February), 54-58.

Goldman, Arieh and J.K. Johansson (1978), "Determinants of Search for Lower Prices: An Empirical Assessment of the Economics of Information Theory," Journal of Consumer Research, 5 (3), 176-86.

Gruca, Thomas S. and Lopo L. Rego (2005), "Customer Satisfaction, Cash Flow, and Shareholder Value," Journal of Marketing, 69 (July), 115-30.

Gupta, Sunil and Donald R. Lehmann (2005), Managing Customers as Investments: The Strategic Value of Customers in the Long Run. Upper Saddle River, NJ: Wharton School Publishing.

Heilman, Carrie M., Douglas Bowman, and Gordon P. Wright (2000), "The Evolution of Brand Preferences and Choice Behaviors of Consumers New to a Market," Journal of Marketing Research, 37 (May), 139-55.

Heskett, James L., Thomas O. Jones, Gary W. Loveman, W. Earl Sasser Jr., and Leonard A. Schlesinger (1994), "Putting the Service-Profit Chain to Work," Harvard Business Review, 72 (March-April), 164-74.

Homburg, Christian and Annette Giering (2001), "Personal Characteristics as Moderators of the Relationship Between Customer Satisfaction and Loyalty: An Empirical Analysis," Psychology \& Marketing, 18 (1), 43-66.

$\longrightarrow, \ldots$, and Ajay Menon (2003), "Relationship Characteristics as Moderators of the Satisfaction-Loyalty Link: Findings in a Business-to-Business Context," Journal of Businessto-Business Marketing, 10 (3), 35-62.

Huber, Peter J. (1980), Robust Statistics. New York: John Wiley \& Sons.

Ittner, Christopher and David F. Larcker (1998), "Are NonFinancial Measures Leading Indicators of Financial Perfor- mance? An Analysis of Customer Satisfaction," Journal of Accounting Research, 36 (Supplement), 1-35.

Jones, Thomas O. and W. Earl Sasser Jr. (1995), "Why Satisfied Customers Defect," Harvard Business Review, 73 (November-December), 88-99.

Kalwani, Manohar U. and Narakesari Narayandas (1995), "LongTerm Manufacturer-Supplier Relationships: Do They Pay Off for Supplier Firms?” Journal of Marketing, 59 (January), 1-16.

Kamakura, Wagner A. and Michel Wedel (1995), "Life-Style Segmentation with Tailored Interviewing," Journal of Marketing Research, 32 (August), 308-317.

Kano, Noriaki, N. (1997), "Upsizing the Organization by Attractive Quality Creation," in The Best on Quality, John D. Hromi, ed. Milwaukee: American Society for Quality, 60-72.

Keaveney, Susan M. and Madhavan Parthasarathy (2001), "Customer Switching Behavior in Online Services: An Exploratory Study of the Role of Selected Attitudinal, Behavioral, and Demographic Factors," Journal of the Academy of Marketing Science, 29 (4), 374-90.

Keiningham, Timothy L., Lerzan Aksoy, Bruce Cooil, Kenneth Peterson, and Terry G. Vavra (2006), "A Longitudinal Examination of the Asymmetric Impact of Employee and Customer Satisfaction on Retail Sales," Managing Service Quality, 16 (5), 442-59.

- - Tiffany Perkins-Munn, and Terry G. Vavra (2005), "The Brand-Customer Connections," Marketing Management, 14 (4), 33-37.

-, Tiffany Perkins-Munn, Lerzan Aksoy, and Demitry Estrin (2005), "Does Customer Satisfaction Lead to Profitability? The Mediating Role of Share of Wallet," Managing Service Quality, 15 (2), 172-81.

— - , and Heather Evans (2003), "The Impact of Customer Satisfaction on Share of Wallet in a Business-toBusiness Environment," Journal of Service Research, 6 (August), 37-50.

and Terry G. Vavra (2001), The Customer Delight Principle: Exceeding Customers' Expectations for Bottom-Line Success. Burr Ridge, IL: McGraw-Hill.

,-- Lerzan Aksoy, and Henri Wallard (2005), Loyalty Myths: Hyped Strategies That Will Put You Out of Business and Proven Tactics That Really Work. Hoboken, NJ: John Wiley \& Sons.

Kim, Byung-Do, Kannan Srinivasan, and Ronald T. Wilcox (1999), "Identifying Price Sensitive Customers: The Relative Merits of Demographic Versus Purchase Pattern Information," Journal of Retailing, 75 (2), 173-93.

Korgaonkar, Pradeep K., Daulat Lund, and Barbara Price (1985), "A Structural Equations Approach Toward Examination of Store Attitude and Store Patronage Behavior," Journal of Retailing, 61 (2), 39-60.

LaBarbera, Priscilla A. and David Mazursky (1983), "A Longitudinal Assessment of Consumer Satisfaction/Dissatisfaction: The Dynamic Aspect of the Cognitive Process," Journal of Marketing Research, 20 (November), 393-404.

Lambert-Pandraud, Raphaëlle, Gilles Laurent, and Eric Lapersonne (2005), "Repeat Purchasing of New Automobiles by Older Consumers: Empirical Evidence and Interpretations," Journal of Marketing, 69 (April), 97-113.

Lenk, Peter J. and Wayne S. DeSarbo (2000), "Bayesian Inference for Finite Mixture Models of Generalized Linear Models with Random Effects," Psychometrika, 65 (1), 93-119.

Loveman, Gary W. (1998), "Employee Satisfaction, Customer Loyalty, and Financial Performance: An Empirical Examination of the Service Profit Chain in Retail Banking," Journal of Service Research, 1 (August), 18-31.

Mägi, Anne W. (2003), "Share of Wallet in Retailing: The Effects of Customer Satisfaction, Loyalty Cards and Shopper Characteristics," Journal of Retailing, 79 (2), 97-106. 
Maheswaran, Durairay (1994), "Country of Origin as a Stereotype: Effects of Consumer Expertise and Attitude Strength on Product Evaluations," Journal of Consumer Research, 21 (September), 354-65.

Marmorstein, Howard, Dhruv Grewal, and Raymond P.H. Fishe (1992), "The Value of Time Spent in Price-Comparison Shopping: Survey and Experimental Evidence," Journal of Consumer Research, 19 (1), 52-61.

McGoldrick, Peter J. and Elisabeth Andre (1997), "Consumer Misbehaviour," Journal of Retailing and Consumer Services, 4 (2), 73-81.

Miller, John A. (1977), "Studying Satisfaction, Modifying Models, Eliciting Expectations, Posing Problems, and Making Meaningful Measurement," in Conceptualization and Measurement of Consumer Satisfaction and Dissatisfaction, H. Keith Hunt, ed. Cambridge, MA: Marketing Science Institute, 72-91.

Mitchell, Andrew A. and Peter A. Dacin (1996), "The Assessment of Alternative Measures of Consumer Expertise," Journal of Consumer Research, 23 (December), 219-39.

Mittal, Vikas and P.M. Baldasare (1996), "Impact Analysis and the Asymmetric Influence of Attribute Performance on Patient Satisfaction," Journal of Health Care Marketing, 16 (3), 24-31.

— and Wagner Kamakura (2001), "Satisfaction, Repurchase Intent, and Repurchase Behavior: Investigating the Moderating Effect of Customer Characteristics," Journal of Marketing Research, 38 (February), 131-42.

- Jerome M. Katrichis, Frank Forkin, and Mark Konkel (1998), "The Asymmetric Impact of Negative and Positive Attribute-Level Performance on Overall Satisfaction and Repurchase Intentions," Journal of Marketing, 62 (January), 33-47.

Moorthy, Sridhar, Brian T. Ratchford, and Debabrata Talukdar (1997), "Consumer Information Search Revisited: Theory and Empirical Analysis," Journal of Consumer Research, 23 (March), 263-77.

Moos, Bob (2004), "Advertisers Try to Appeal to Over-50 Boomers," Knight Ridder/Tribune Business News, (October 31), 1.

Murphy, Patrick E. (1978), "The Effect of Social Class on Brand and Price Consciousness for Supermarket Products," Journal of Retailing, 54 (2), 33-42, 89.

Murthi, B.P.S. and Kannan Srinivasan (1999), "Consumers' Extent of Evaluation in Brand Choice," Journal of Business, 72 (2), 229-56.

Newman, Joseph W. and Richard A. Werbel (1973), "Multivariate Analysis of Brand Loyalty for Major Household Appliances," Journal of Marketing Research, 10 (November), 404-409.

Oliva, Terence A., Richard L. Oliver, and Jan C. MacMillan (1992), "A Catastrophe Model for Developing Service Satisfaction Strategies," Journal of Marketing, 58 (July), 83-95.

Oliver, Richard L. (1980), "A Cognitive Model of the Antecedents and Consequences of Satisfaction Decisions," Journal of Marketing Research, 17 (November), 460-69.

- (1997), Satisfaction: A Behavioral Perspective on the Consumer. New York: McGraw-Hill/Richard D. Irwin.

_ (1999), "Whence Consumer Loyalty?" Journal of Marketing, 63 (July), 33-44.

- Roland T. Rust, and Sajeev Varki (1997), "Customer Delight: Foundations, Findings and Managerial Insight," Journal of Retailing, 7 (3), 311-36.

Parasuraman, A., Valarie A. Zeithaml, and Leonard L. Berry (1988), "SERVQUAL: A Multiple-Item Scale for Measuring Consumer Perceptions of Service Quality," Journal of Retailing, 64 (Spring), 12-40.

Perkins-Munn, Tiffany, Lerzan Aksoy, Timothy L. Keiningham, and Demitry Estrin (2005), "Actual Purchase as a Proxy for Share of Wallet," Journal of Service Research, 7 (3), 245-56.
Peterson, Robert A. and William R. Wilson (1992), "Measuring Customer Satisfaction: Fact and Artifact," Journal of the Academy of Marketing Science, 20 (1), 61-71.

Rao, C.R. and Y. Wu (1989), "A Strongly Consistent Procedure for Model Selection in a Regression Problem," Biometrika, 76 (2), 369-74.

Reichheld, Frederick F. (1993), "Loyalty-Based Management," Harvard Business Review, 71 (2), 64-73.

(1996), "Learning from Customer Defections," Harvard Business Review, 74 (2), 56-69.

- and David W. Kenny (1991), "The Hidden Advantages of Customer Retention," Journal of Retail Banking, 12 (4), 19-23. , Robert G. Markey Jr., and Christopher Hopton (2000), "The Loyalty Effect: The Relationship Between Loyalty and Profits," European Business Journal, 12 (3), 134-39.

- and W. Earl Sasser Jr. (1990), "Zero Defections: Quality Comes to Services," Harvard Business Review, 68 (5), $105-111$.

Reinartz, Werner and V. Kumar (2000), “On the Profitability of Long-Life Customers in a Noncontractual Setting: An Empirical Investigation and Implications for Marketing," Journal of Marketing, 64 (October), 17-35.

- and (2002), "The Mismanagement of Customer Loyalty," Harvard Business Review, 80 (July), 86-94.

Ross, Linda W., Robert S. Fleming, Keith J. Fabes, and Razelle Frankl (1999), "Gender Effects on Customer Satisfaction with Employment Services," Career Development International, 4 (5), 270-76.

Rust, Roland T. (2002), personal interview, in The Customer Delight Principle Video, Timothy L. Keiningham and Terry G. Vavra, hosts. Brentwood, TN: Titus Productions.

, Katherine N. Lemon, and Valarie A. Zeithaml (2004), "Return on Marketing: Using Customer Equity to Focus Marketing Strategy," Journal of Marketing, 68 (January), 109-127.

__ - Duncan Simester, Roderick Brodie, and V. Nilikant (1995), "Model Selection Criteria: An Investigation of Relative Accuracy, Posterior Probabilities and Combinations of Criteria," Management Science, 41 (2), 322-33.

and Anthony J. Zahorik (1993), "Customer Satisfaction, Customer Retention, and Market Share," Journal of Retailing, 69 (2), 193-215.

- - , and Timothy L. Keiningham (1994), Return on Quality: Measuring the Financial Impact of Your Company's Quest for Quality. Chicago: Richard D. Irwin.

- — - and (1995), "Return on Quality (ROQ): Making Service Quality Financially Accountable," Journal of Marketing, 59 (April), 58-70.

Sambandam, Rajan and Kenneth R. Lord (1995), "Switching Behavior in Automobile Markets: A Consideration Sets Model," Journal of the Academy of Marketing Science, 23 (Winter), 57-65.

Satorra, Albert (2002), "Asymptotic Robustness in Multiple Group Linear-Latent Variable Models," Econometric Theory, 18 (2), 297-312.

Schwarz, G. (1978), "Estimating the Dimension of a Model," Annals of Statistics, 6 (2), 461-64.

Sharir, Samuel (Shraier) (1974), "Brand Loyalty and the Household's Cost of Time," Journal of Business, 47 (1), 53-55.

Silvestro, Rhian and Stuart Cross (2000), "Applying the Service Profit Chain in a Retail Environment," International Journal of Service Industry Management, 11 (3), 244-68.

Stern, Philip and Kathy Hammond (2004), "The Relationship Between Customer Loyalty and Purchase Incidence," Marketing Letters, 15 (1), 5-19.

Steyerberg E.W., F.E. Harrell Jr., G.J. Borsboom, M.J. Eijkemans, Y. Vergouwe, and J.D. Habbema (2001), "Internal Validation of Predictive Models: Efficiency of Some Procedures for Logistic 
Regression Analysis," Journal of Clinical Epidemiology, 54 (8), 774-81.

Swan, John E. and Linda Jones Combs (1976), "Product Performance and Consumer Satisfaction: A New Concept," Journal of Marketing, 40 (April), 25-33.

Udell, Jon G. (1966), "Prepurchase Behavior of Buyers of Small Electrical Appliances," Journal of Marketing, 30 (October), 50-52.

Uncles, Mark D., Grahame R. Dowling, and Kathy Hammond (2003), "Customer Loyalty and Customer Loyalty Programs," Journal of Consumer Marketing, 20 (4), 294-316.

, Andrew Ehrenberg, and Kathy Hammond (1995), "Patterns of Buyer Behavior: Regularities, Models, and Extensions (in Stochastic Choice Phenomena)," Marketing Science, 14 (3), G71-G78.

Varki, Sajeev and Roland T. Rust (1997), "Satisfaction Is Relative: Apply Analysis of Variance Techniques to Determine if Your CSM Scores Measure Up," Marketing Research, 9 (Summer), $15-19$.

Venn, Sally and David L. Fone (2005), "Assessing the Influence of Socio-Demographic Factors and Health Status on Expression of Satisfaction with GP Services," Clinical Governance, 10 (2), $118-25$.

Verhoef, Peter C., Philip Hans Franses, and Janny C. Hoekstra (2001), "The Impact of Satisfaction and Payment Equity on Cross-Buying: A Dynamic Model for a Multi-Service Provider," Journal of Retailing, 77 (3), 359-78.
Vermunt, J.K. (2003), "Multilevel Latent Class Models," Sociological Methodology, 33 (1), 213-39.

Wind, Yoram (1970), "Industrial Source Loyalty," Journal of Marketing Research, 7 (November), 450-57.

Woodroofe, Michael (1982), "On Model Selection and the Arc Sine Laws," Annals of Statistics, 10 (4), 1182-94.

Wright, Claire and Leigh Sparks (1999), "Loyalty Saturation in Retailing: Exploring the End of Retail Loyalty Cards?" International Journal of Retail \& Distribution Management, 27 (10), 429-39.

Yi, Youjae (1990), "A Critical Review of Consumer Satisfaction," in Review of Marketing, Valarie A. Zeithaml, ed. Chicago: American Marketing Association, 68-123.

Zabin, Jeff and Gresh Brebach (2004), Precision Marketing: The New Rules for Attracting, Retaining, and Leveraging Profitable Customers. Hoboken, NJ: John Wiley \& Sons.

Zeithaml, Valarie A. (1985), "The New Demographics and Market Fragmentation," Journal of Marketing, 49 (July), 64-75.

(2000), "Service Quality, Profitability, and the Economic Worth of Customers: What We Know and What We Need to Learn," Journal of the Academy of Marketing Science, 28 (1), $67-85$.

, Leonard L. Berry, and A. Parasuraman (1996), "The Behavioral Consequences of Service Quality," Journal of Marketing, 60 (April), 31-46. 
Copyright of Journal of Marketing is the property of American Marketing Association and its content may not be copied or emailed to multiple sites or posted to a listserv without the copyright holder's express written permission. However, users may print, download, or email articles for individual use. 